\title{
The effectiveness of a 12-day training program restoring aerobic capacity after a break in training at football players'
}

\section{Účinnost 12denního tréninkového programu pro obnovení aerobní kapacity po přestávce $v$ tréninku u fotbalistů}

\author{
Tomasz Gabrys ${ }^{1,2}$, Michal Garnys ${ }^{3}$, Arkadiusz Stanula ${ }^{4}$, Urszula Szmatlan-Gabrys ${ }^{2}$, Marek Szczerbowski ${ }^{5}$ \\ ${ }^{1}$ Institut of Physical Education, Tourism and Physioterapy, University Jan Dlugosz in Czestochowa, Poland \\ ${ }_{2}^{2}$ Institute of Physical Education and Sport, State School of Higher Education in Oświęcim Poland \\ ${ }^{3}$ 4SportLab, Laboratory of Physical Preparation, Warsaw, Poland, \\ ${ }^{4}$ Department of Sports Training, The Jerzy Kukuczka Academy of Physical Education in Katowice, Poland \\ ${ }^{5}$ Faculty of Managing Sport and Tourism The Jerzy Kukuczka Academy of Physical Education in Katowice, \\ Poland
}

\begin{abstract}
The occurrence of detraining in sports disciplines characterized by an extended starting period has to be taken into consideration whilst devising the sports training program. The aim of this study was the evaluation of the effectiveness of the applied 12-day training program, which was to minimalize the effects of detraining in a group of Polish Major League football players. The training program applied, based on a total load volume, in two micro cycles in the particular zones: $1^{\circ} 28$, and $31 \mathrm{~km}, 11^{\circ} 24$, and $26.5 \mathrm{~km}, I 1 I^{\circ} 18$, and $19.8 \mathrm{~km}$, influences a significant aerobic capacity precipitation of competitors after a 14-day detraining period. The increase of indicator value were: $V_{2}$ max by $12 \%, V . L T$ by $7 \%$, and V.AT by $10 \%$. Due to choosing the proportions of training loads in I, II, and III intensity range, it is possible to include competitors with various levels of aerobic capacity in one training group. The basis of such a solution is determining individual workout intensities while the volume is the same for the whole team.
\end{abstract}

\begin{abstract}
Abstrakt
Pri tvorbě sportovního tréninku je třeba vzít v úvahu výskyt výpadku v tréninku charaterizovaný prodlouženým počátečním obdobím. Cílem této studie bylo zhodnotit efektivitu aplikovaného 12 denního tréninkového programu, jehož cílem bylo minimalizovat vliv výpadku v tréninku ve skupině fotbalistů z Polské hlavní ligy. Výcvikový program založený na celkovém objemu zatížení ve dvou mikrocyklech v jednotlivých zónách: $I^{\circ} 28$ a $31 \mathrm{~km}, I^{\circ} 24$ a 26,5km, III0 18 a 19,8km, ovlivňuje významné snízení aerobní kapacity sportovnců po 14denním výpadku tréninku. Zvýšení hodnoty indikátoru bylo: $\mathrm{VO}_{2}$ max o 12\%, V.LT o 7\% a V.AT o 10\%. Vzhledem k volbě poměru tréninkových zátěží v rozsahu intenzity l, II a III je možné zahrnout do jedné tréninkové skupiny soutěžici s různou úrovní aerobní kapacity. Základem takového řešení je určení intenzity individuálního cvičení, zatímco objem je pro celý tým stejný.
\end{abstract}

Keywords: aerobic capacity, training, football players, detraining

Klíčová slova: aerobní kapacita, trénink, fotbaloví hráči, výpadek v tréninku

\section{Acknowledgements}

This scientific work was funded by the Minister of Science and Higher Education from the 2012-2016 programme "The Development of Academic Sport"; project no. NRSA2 04852 


\section{INTRODUCTION}

The issue of detraining is an important element of training load planning in sport disciplines characterized by an extended starting period. Breaks in the training process related to the competitors' winter, and summer holidays, have a significant influence on the level of motor preparation (Hawley, Burke 1998, Schneider et al. 1998) The partial, or total cut-off of training stimuli application, leads to a significant decrease in effort adaptation. A fast decrease in aerobic capacity level indicators (including $\mathrm{VO}_{2} \max$ ) was observed in good competitors (Hickson et al. 1982, Hickson et al. 1981). The result of a break in regular training, is an increase in the frequency of systoles during effort. The increase is insufficient to be a counterbalance to the decreased stroke volume. This leads to reducing the maximal cardiac output (Coyle et al. 1984). Parallel to a decrease in heart performance, is a decrease in the performance of the respiratory system (Martin et al. 1986). The detrimental changes do not occur in short time periods. In order for the whole training effect to be lost, as far as the value of the indicator is concerned, the break has to last for over 4 weeks (Coyle, Martin 1985, Houmard et al 1993). The aforementioned functions of the trained organism lose their efficiency to different extents, and over different timespans. In blood volume, the changes occur very fast, and the decrease in the first days of decreasing training loads, is within the 5-12\% range, in competitors well trained in terms of stamina (Coyle et al. 1986, Houmard et al. 1992, Thompson et al. 1984). Changes in blood plasma volume are visible after a two day break in training (Culinane et al. 1986). This is the result of decreases in both, the volume of red blood cells, and of plasma (Pivarnik, Senay 1986). The frequency of systoles increases during submaximal and maximum effort within the range of 5-10\% (Madsen et al. 1993). The greatest increase in HR is observed in the $2^{\text {nd }}$ and $3^{\text {rd }}$ week since stopping training (Coyle et al 1984). A decrease in stroke volume, which takes place within 12-21days since reducing the training loads by $10-17 \%$, is related to a decrease in blood volume (Coyle et al 1984). Maximum stroke volume decreases by $8 \%$ after 21 days, whereas submaximal stroke volume goes from 84 to $89 \%$ (Coyle et al 1984). Off course the changes in the efficiency of the competitor's bodily functions influence $\mathrm{VO}_{2}$ max value directly. A decrease resulting from a break in training within the 4-14\% range, has been observed in many studies (Coyle et al 1984, Martin et. Al 1986, Moore et al. 1987, Coyle et al. 1986, Ghosh et al. 1987). 40 claims that the higher the trained $\mathrm{VO}_{2}$ max level, the greater the range of a decrease in its value. Parallel to the decrease in $\mathrm{VO}_{2} \max$ value, there is a decrease in $\mathrm{VE}$ and $\mathrm{O}_{2}$ pulse (Huston et al. 1979, Ghosh et al. 1987, Cullinane, Sady 1986).

Off course, all the aforementioned changes in the bodily functions influence the competitor's efficiency level (Huston et al. 1979, Coyle et al 1986, Claude, Sharp 1991, Maudsen et al. 1993). A short break in training, which usually is not the result of injury, but of the organization of training cycles, and sports events, also entails changes in the athlete's metabolism. The respiratory exchange ratio (RER) increases as far as the submaximal, and maximum values are concerned. This is the result of the increased participation of carbohydrates in efforts of such nature (Coyle et al. 1984, Moooore et al. 1987, Houmard et al. 1992, Maudsen et al. 1993). A decrease in the level of GLUT-4, which transports glicose in muscle tissue, by 17-33\%, after 6-10 days without training has a significant influence on the changes in muscle metabolism (McCoy et al. 1994, Vukovich et al. 1996). The anaerobic exercise level corresponds to the lover percentage of $\mathrm{VO}_{2} \max$, which results from a decrease in the muscles' oxidative capacity to $50 \%$ in the first week of the break (Costilll et al. 1985). The detrimental changes related to the break in training, also include: muscle capillarisation (Coyle et al. 1984), myoglobin levels (Coyle et al. 1984), muscle enzyme activity (Bangsbo, Mizuno 1987, Coyle et al. 1984, Houmard et al. 1992, McCoy et al. 1994, Mikines et al. 1989), and mitochondrial ATP production (Wibom et al. 1992). Such a wide range of detrimental changes has to be taken into account while planning training after a break in the regular 
use of training loads. Training should include two stages: 1 . The evaluation of the current level of the competitors' fitness, and 2. The implementation of the program allowing the reconstruction of the lost level of bodily functions. The aim of the research carried out, was the evaluation of efficiency of the training solution aimed at reconstructing the aerobic capacity after the 14-day break in the training of football players.

\section{RESEARCH MATERIAL, AND METHODOLOGY}

Research material consisted of 24 Polish Mayor League football players. The research was carried out after a 14-day winter break in the game, and after the competitors' holidays. The experiment assumed carrying out the aerobic capacity research twice, and implementing a special training program, whose aim was to significantly increase the $\mathrm{VO}_{2}$ max level in competitors with the lowest values of it. The evaluation of aerobic capacity was carried out on the basis of an exercise test, during which competitors running the distance of 40 meters, increased their running speed every two minutes by $2 \mathrm{~km} / \mathrm{h}$, starting from $8 \mathrm{~km} / \mathrm{h}$. The running speed was designated by means of an acoustic signal. $\mathrm{VO}_{2}, \mathrm{VE}, \mathrm{VCO}_{2}$, and $\mathrm{HR}$ values were measured before, and during the effort, as well as for 5 minutes after it ended (K4b2 Cosmed, Italy). Blood lactate concentration value was measured by means of the enzymatic-amperometric method using chip-sensor technology. (Biosen C-line, EKF Germany). The blood was drawn from fingertips after the end of each of the stages of the run. The values of $\mathrm{V}(\mathrm{km} / \mathrm{h})$, and HR were designated for the anaerobic threshold (AT), in accordance with the Wasserman et al.(1973) method -VAT, and HRAT, and for the lactate threshold, according to the $\Delta 1 \mathrm{mmol}$ method VLT, and HRLT (Thoden 1991)..The subjects were divided into groups according to the degree of $\mathrm{VO}_{2} \max$, VLAT, and VAT decrease, compared to the starting period. Group $1(n=14)$, were the football players whose aerobic capacity indicators decreased by $11-20 \%$. Group $2(n=10)$, were the competitors, whose decrease in indicator value ranged from 0 to $10 \%$. The training was carried out in two 6-day micro cycles with 3 levels of intensity: $\mathrm{LT} \leq \mathrm{I}^{\circ} \leq 1 / 2 \mathrm{LT}-\mathrm{AT}$ (aerobic), $1 / 2 \mathrm{LT}$ - AT $\leq \mathrm{II}^{\circ} \leq \mathrm{AT}$ (aerobic-anaerobic) $\mathrm{AT} \leq \mathrm{III}^{\circ} \leq \mathrm{AT}+15 \%$ (anaerobic). The contents of the training run program, and of the football player's special training during the first micro cycle, are presented in table 1. During the second micro cycle, the volume of training run measures was increased by $10 \%$.

Tab. 1: Training loads for the experimental program

\begin{tabular}{|c|c|c|}
\hline Day & I training $\mathbf{1 0 . 0 0}$ & II training 17.00 \\
\hline 1 & $\begin{array}{l}\text { Run } 2 \times 12 \min 6 \min \left(\mathrm{I}^{\circ}\right)-6 \min \left(3 \min \mathrm{II}^{\circ},\right. \\
3 \mathrm{~min}\left(\mathrm{II}^{\circ}\right) \text { p. } 12 \min \text { gymnastic, soccer tactic } \\
\end{array}$ & Soccer drils $\left(\mathrm{I}^{\circ}\right)$, strenght $\left(\mathrm{I}^{\circ}\right)$ \\
\hline 2 & Run $3 \times 12$ min (1-st day program) & $\begin{array}{l}\text { Technique }(\mathrm{I}) \text {, strenght run }\left(\mathrm{III}^{\circ}\right) \text {, } \\
\text { Play } 15 \min \left(\mathrm{I}^{\circ}\right)\end{array}$ \\
\hline 3 & $\begin{array}{l}\text { Aerobic capacity: } 4 \times 1200 \mathrm{~m}\left(\mathrm{III}^{\circ}\right) \text {, } \\
\text { (time work to rest. } 1: 1) \text {, play }\left(\mathrm{I}^{\circ}\right)\end{array}$ & $\begin{array}{l}\text { Coordination drils, run strenght } 10 \times 15 \mathrm{~s} \text {, } \\
\text { drills with futbol: technical elements }\left(\mathrm{I}^{\circ} \text { i } \mathrm{II}^{\circ}\right)\end{array}$ \\
\hline 4 & $\begin{array}{l}\text { Aerobic capacity: } 5 \times 1200 \mathrm{~m}\left(\mathrm{III}^{\circ}\right) \\
\text { (time work to rest. } 1: 1) \text {, play }\left(\mathrm{I}^{\circ}\right)\end{array}$ & $\begin{array}{l}\text { Coordination drils } 10 \times 15 \mathrm{~s} \\
\text { Teaching play }\end{array}$ \\
\hline 5 & $\begin{array}{l}\text { Aerobic capacity: } 6 \times 1200 \mathrm{~m}(\mathrm{III}) \text {, } \\
\text { (time work to rest. } 1: 1) \text {, play }\left(\mathrm{I}^{\circ}\right)\end{array}$ & Rest \\
\hline 6 & Drills with ball & Play $11 \times 11\left(\mathrm{II}^{\circ}\right)$, tactics \\
\hline
\end{tabular}




\section{RESEARCH RESULTS}

Tables 2, and 3 present the values of physiological indicators recorded in two groups of football players doing the experimental program. The mean value of $\mathrm{VO}_{2}$ max in group $1-49.79 \pm 3.42 \mathrm{ml} /$ $\mathrm{kg} / \mathrm{min}$, and the speed levels at LT $-10,75 \pm 0,38 \mathrm{~km} / \mathrm{h}$, and AT $-12,79 \pm 0,61 \mathrm{~km} / \mathrm{h}$ thresholds, indicate a low level of aerobic endurance. The HRmax values which in the group, on average amount to $203 \pm 11 \mathrm{ud} / \mathrm{min}$ do not indicate the subjects' fatigue or overtraining Indicator values in group 2, $\mathrm{VO}_{2} \max -56 \pm 2,42 \mathrm{ml} / \mathrm{kg} / \mathrm{min}$, and speed levels at the LT $-11,86 \pm 0,61 \mathrm{~km} / \mathrm{h}$, and AT $-13,93 \pm 0,47 \mathrm{~km} / \mathrm{h}$ thresholds, are significantly higher statistically. (table 4 ). They also do not significantly differ from the values recorded during the season and adopted as reference values at the preparation stage. The HR values which in group 2 on average amount to $202 \pm 7,85 \mathrm{ud} /$ min, do not indicate the subjects' fatigue or overtraining. This is confirmed by the lack of relevant differences in HRmax, and HR values recorded at metabolic thresholds (HR.LT, and HR.AT). The appearance of differences in values in the case of one internal-( $\left.\mathrm{VO}_{2} \mathrm{max}\right)$, and two external load indicators (V.LT, and V.AT) shows that these are the three indicators most sensitive to a break, or a significant decrease in football players' training. The values of internal loads indicators: HRmax, HR.LT, and HR.AT do not show such sensitivity.

Tab. 2: Characteristics of rates of the aerobic capacity I group football players before (1) and after (2) of achievement of the experimental program.

\begin{tabular}{|c|c|c|c|c|c|c|c|}
\hline \multirow{2}{*}{$\begin{array}{l}\text { Physiological } \\
\text { parameters }\end{array}$} & \multirow{2}{*}{ Invest. } & \multicolumn{6}{|c|}{ Statistical parameters } \\
\hline & & Mean \pm SD & Median & Range & $\mathrm{CV}$ & Skewness & Kurtosis \\
\hline \multirow{2}{*}{$\begin{array}{l}\mathrm{VO}_{2} \mathrm{max} \\
\mathrm{ml} / \mathrm{kg} / \mathrm{min}\end{array}$} & 1 & $49,79 \pm 3,42$ & 49,5 & $44-55$ & 6,88 & $-0,083$ & $-1,033$ \\
\hline & 2 & $56 \pm 2,42$ & 56 & $53-60$ & 4,32 & 0,267 & $-1,463$ \\
\hline \multirow{2}{*}{$\begin{array}{l}\text { HRmax } \\
\text { bp/min }\end{array}$} & 1 & $184,6 \pm 11,49$ & 188 & $166-203$ & 6,22 & $-0,280$ & $-1,027$ \\
\hline & 2 & $187,8 \pm 7,85$ & 189 & $173-202$ & 4,18 & $-0,196$ & $-0,261$ \\
\hline \multirow{2}{*}{$\begin{array}{l}\text { Vmax } \\
\text { km/h }\end{array}$} & 1 & $15,86 \pm 0,36$ & 16 & $15-16$ & 2,29 & $-2,295$ & 3,792 \\
\hline & 2 & $17,36 \pm 0,84$ & 18 & $16-18$ & 4,85 & $-0,829$ & $-1,017$ \\
\hline \multirow{2}{*}{$\begin{array}{l}\text { VLT } \\
\mathrm{km} / \mathrm{h}\end{array}$} & 1 & $10,75 \pm 0,58$ & 11 & $10-12$ & 5,40 & 0,172 & 0,203 \\
\hline & 2 & $11,86 \pm 0,66$ & 12 & $11-13$ & 5,59 & 0,151 & $-0,310$ \\
\hline \multirow{2}{*}{$\begin{array}{l}\text { VAT } \\
\mathrm{km} / \mathrm{h}\end{array}$} & 1 & $12,79 \pm 0,61$ & 13 & $12-14$ & 4,78 & $-0,487$ & 1,151 \\
\hline & 2 & $13,93 \pm 0,47$ & 140 & $13-15$ & 3,41 & $-0,308$ & 2,923 \\
\hline \multirow{2}{*}{$\begin{array}{l}\text { HRLT } \\
\text { bp/min }\end{array}$} & 1 & $149,1 \pm 10,08$ & 149 & $133-162$ & 6,76 & $-0,256$ & $-1,262$ \\
\hline & 2 & $156,7 \pm 8,11$ & 157 & $144-165$ & 5,17 & $-0,450$ & $-1,304$ \\
\hline \multirow{2}{*}{$\begin{array}{l}\text { HRAT } \\
\text { bp/min }\end{array}$} & 1 & $167,6 \pm 10,79$ & 171 & $152-182$ & 6,44 & $-0,362$ & $-1,587$ \\
\hline & 2 & $173,1 \pm 7,61$ & 176,5 & $160-180$ & 4,40 & $-0,814$ & $-0,961$ \\
\hline
\end{tabular}


Tab. 3: Characteristics of rates of the aerobic capacity II group football players before (1) and after (2) of achievement of the experimental program.

\begin{tabular}{|c|c|c|c|c|c|c|c|}
\hline \multirow{2}{*}{$\begin{array}{l}\text { Physiological } \\
\text { parameters }\end{array}$} & \multirow{2}{*}{ Invest. } & \multicolumn{6}{|c|}{ Statistical parameters } \\
\hline & & Mean \pm SD & Median & Range & $\mathrm{CV}$ & Skewness & Kurtosis \\
\hline \multirow{2}{*}{$\begin{array}{l}\mathrm{VO}_{2} \mathrm{max} \\
\mathrm{ml} / \mathrm{kg} / \mathrm{min}\end{array}$} & 1 & $59,6 \pm 2,22$ & 59 & $57-65$ & 3,73 & 1,697 & 3,852 \\
\hline & 2 & $60,2 \pm 1,93$ & 60 & $58-65$ & 3,21 & 1,844 & 4,450 \\
\hline \multirow{2}{*}{$\begin{array}{l}\text { HRmax } \\
\text { bp/min }\end{array}$} & 1 & $178 \pm 9,70$ & 179 & $160-194$ & 5,44 & $-0,250$ & 0,376 \\
\hline & 2 & $184,6 \pm 7,79$ & 186 & $172-195$ & 4,22 & $-0,436$ & $-0,599$ \\
\hline \multirow{2}{*}{$\begin{array}{l}\text { Vmax } \\
\mathrm{km} / \mathrm{h}\end{array}$} & 1 & $17 \pm 0,82$ & 17 & $16-18$ & 4,80 & 0,000 & $-1,393$ \\
\hline & 2 & $17,5 \pm 0,53$ & 18 & $17-18$ & 3,01 & 0,000 & $-2,571$ \\
\hline \multirow{2}{*}{$\begin{array}{l}\text { VLT } \\
\mathrm{km} / \mathrm{h}\end{array}$} & 1 & $11,2 \pm 0,58$ & 11 & $10-12$ & 5,20 & $-0,192$ & 1,092 \\
\hline & 2 & $12,2 \pm 0,42$ & 12 & $12-13$ & 3,46 & 1,779 & 1,406 \\
\hline \multirow{2}{*}{$\begin{array}{l}\text { VAT } \\
\mathrm{km} / \mathrm{h}\end{array}$} & 1 & $13,4 \pm 0,52$ & 13 & $13-14$ & 3,85 & 0,484 & $-2,277$ \\
\hline & 2 & $14,2 \pm 0,63$ & 14 & $13-15$ & 4,45 & $-0,132$ & 0,179 \\
\hline \multirow{2}{*}{$\begin{array}{l}\text { HRLT } \\
\text { bp/min }\end{array}$} & 1 & $154 \pm 9,42$ & 156 & $136-168$ & 6,11 & $-0,689$ & 0,362 \\
\hline & 2 & $159 \pm 6,58$ & 160 & $145-170$ & 4,14 & $-0,643$ & 2,038 \\
\hline \multirow{2}{*}{$\begin{array}{l}\text { HRAT } \\
\text { bp/min }\end{array}$} & 1 & $170,3 \pm 7,80$ & 171 & $157-181$ & 4,58 & $-0,455$ & $-0,215$ \\
\hline & 2 & $174,6 \pm 5,44$ & 175 & $165-180$ & 3,12 & $-1,186$ & 0,382 \\
\hline
\end{tabular}

Tab. 4: Statistical characteristics of the difference between values rates of the aerobic capacity registered in 1 and 2 group after training break

\begin{tabular}{|l|r|c|c|c|}
\hline \multirow{2}{*}{$\begin{array}{l}\text { Physiological } \\
\text { parameters }\end{array}$} & \multicolumn{4}{|c|}{ Statistical parameters } \\
\cline { 2 - 5 } VO $\mathbf{t}$ max & $\mathbf{- 7 , 9 2 6}$ & $\mathbf{0 , 0 0 0}$ & $\mathbf{2 , 3 7 6}$ & $\mathbf{0 , 1 9 8}$ \\
\hline HRmax & 1,404 & 0,174 & 1,404 & 0,620 \\
\hline Vmax & $\mathbf{- 4 , 6 6 1}$ & $\mathbf{0 , 0 0 0}$ & $\mathbf{5 , 0 5 6}$ & $\mathbf{0 , 0 0 9}$ \\
\hline V.LT & $-1,666$ & 0,110 & 1,001 & 1,000 \\
\hline V.AT & $\mathbf{- 2 , 5 8 3}$ & $\mathbf{0 , 0 1 7}$ & $\mathbf{1 , 4 0 1}$ & $\mathbf{0 , 6 2 2}$ \\
\hline HR.LT & $-1,196$ & 0,245 & 1,145 & 0,859 \\
\hline HR.AT & $-0,681$ & 0,503 & 1,912 & 0,333 \\
\hline
\end{tabular}

Tables 5, and 6 show the extent of difference, direction, and level of the statistical significance of the change in indicator value differences in terms of their statistical significance between tests 1 , and 2. In group 1, values of all indicators underwent statistically significant change.

The direction of the changes in values is positive in the case of all indicators, proving their increase. A particularly high progression is visible in the case of $\mathrm{VO}_{2}$ max value (12\%), and running threshold speeds $7-10 \%$ (V.LT, and V.AT respectively). The statistically significant $5 \%$ increase also characterizes the changes in systole frequency at an intensity corresponding to running threshold frequencies (HR.LT, and HR.AT). The increase in the maximal oxygen consumption is accompanied by changes in effort effectiveness indicator levels. It is an increase in HR values at metabolic thresholds (HR.LT p 0. 005, and HR.AT $\mathrm{p} \leq 0.001$ ). The changes in these load indicators are particularly important, as they influence changes in exercise load zones employed in training. 
Tab. 5: Statistical characteristics of differences between values of rates of the aerobic capacity I group football players registered after the achievement of the experimental programme.

\begin{tabular}{|l|c|c|c|c|c|c|c|c|}
\hline \multirow{2}{*}{$\begin{array}{l}\text { Physiological } \\
\text { parameters }\end{array}$} & \multicolumn{9}{|c|}{ Statistical parameters } \\
\cline { 2 - 9 } & Different & $\begin{array}{c}\text { Direction } \\
\text { of changes }\end{array}$ & SD & $\mathbf{t}$ & $\mathbf{d f}$ & $\mathbf{p}$ & \multicolumn{2}{c|}{ Confidence level 95\% } \\
\hline VO max & 6,21 & $\uparrow$ & 2,08 & $-11,17$ & 13 & 0,000 & $-7,42$ & $-5,01$ \\
\hline HRmax & 3,21 & $\uparrow$ & 4,96 & $-2,42$ & 13 & 0,031 & $-6,08$ & $-0,35$ \\
\hline Vmax & 1,5 & $\uparrow$ & 0,65 & $-8,63$ & 13 & 0,000 & $-1,88$ & $-1,12$ \\
\hline V.LT & 1,11 & $\uparrow$ & 0,56 & $-7,39$ & 13 & 0,000 & $-1,43$ & $-0,78$ \\
\hline V.AT & 1,14 & $\uparrow$ & 0,41 & $-10,36$ & 13 & 0,000 & $-1,38$ & $-0,9$ \\
\hline HR.LT & 7,57 & $\uparrow$ & 3,92 & $-7,23$ & 13 & 0,000 & $-9,83$ & $-5,31$ \\
\hline HR.AT & 5,57 & $\uparrow$ & 4,22 & $-4,94$ & 13 & 0,000 & $-8,01$ & $-3,14$ \\
\hline
\end{tabular}

Tab. 6: Statistical characteristics of differences between values of rates of the aerobic capacity II group football players registered after the achievement of the experimental programme.

\begin{tabular}{|l|c|c|c|c|c|c|c|c|}
\hline \multirow{2}{*}{$\begin{array}{l}\text { Physiological } \\
\text { parameters }\end{array}$} & \multicolumn{7}{|c|}{ Statistical parameters } \\
\cline { 2 - 9 } & Different & $\begin{array}{c}\text { Direction } \\
\text { of changes }\end{array}$ & $\begin{array}{c}\text { SD } \\
\text { Diff. }\end{array}$ & $\mathbf{t}$ & $\mathbf{d f}$ & $\mathbf{p}$ & \multicolumn{2}{c|}{ Confidence level 95\% } \\
\hline VO $\mathbf{2}$ max & $-0,60$ & $\uparrow$ & 0,97 & $-1,96$ & 9 & 0,081 & $-1,29$ & 0,09 \\
\hline HRmax & $-6,30$ & $\uparrow$ & 9,51 & $-2,09$ & 9 & 0,066 & $-13,10$ & 0,50 \\
\hline Vmax & $-0,50$ & $\uparrow$ & 0,85 & $-1,86$ & 9 & 0,096 & $-1,11$ & 0,11 \\
\hline V.LT & $-1,05$ & $\uparrow$ & 0,37 & $-9,00$ & 9 & 0,000 & $-1,31$ & $-0,79$ \\
\hline V.AT & $-0,80$ & $\uparrow$ & 0,42 & $-6,00$ & 9 & 0,000 & $-1,10$ & $-0,50$ \\
\hline HR.LT & $-5,00$ & $\uparrow$ & 3,92 & $-4,04$ & 9 & 0,003 & $-7,80$ & $-2,20$ \\
\hline HR.AT & $-4,30$ & $\uparrow$ & 2,98 & $-4,56$ & 9 & 0,001 & $-6,43$ & $-2,17$ \\
\hline
\end{tabular}

The effectiveness of the program was evaluated on the basis of one criterion in both groups. The criterion was the range of change in the values of indicators characterizing aerobic capacity. Due to the choice of intensity, the training program used, was intended for the competitors from group 1. Carrying it out in group 2, was to answer the question if the assumed volume, and intensity of training loads was also stimulating for the increase in stamina in competitors in whom the phenomenon of detraining had not occurred. Changes in aerobic capacity indicator values were expected, first and foremost, in the first group of football players. In this group, whose characteristics were $\mathrm{VO}_{2}$ max values low in comparison to those recorded in the starting period, the increase was of the order of $11 \%(\mathrm{p} \leq 0.001)$. In group 2 , the aerobic capacity indicator values did not differ from the ones registered during the starting period by more than $5 \%$. In this group, after the experimental training, the increase in $\mathrm{VO}_{2}$ max values was not statistically significant. Such an increase was, however, demonstrated in the values of: V.LT ( $p \leq 0.001)$, V.AT $(p \leq 0.001)$, HR.AT $(p \leq 0.001)$, and HR.LT $(p \leq 0.005)$. Thus, it can be stated, that the proposed loads program in the group characterized by a slight decrease of aerobic capacity indicator value, caused an increase in internal loads, corresponding to AT, and LT thresholds, and a higher internal loads tolerance (an increase in HR values while running intensely at both metabolic thresholds).

The conducted experimental program also led to a significant decrease of differences concerning particular aerobic capacity indicators of football players. After the end of two 6 week mezocycles, the statistically significant difference concerned one internal load indicator $-\mathrm{VO}_{2} \mathrm{max}$ value ( $\mathrm{p} \leq 0.001)$ (tab. 7). The statistically significant differences between external load indicators (V.LT, and V.AT) that were recorded before the training began, were not stated after it ended. 
Tab. 7: Statistical characteristics of differences between values of rates of the aerobic capacity I and II group football players registered after the achievement of the experimental programme.

\begin{tabular}{|l|r|c|c|c|}
\hline \multirow{2}{*}{$\begin{array}{l}\text { Physiological } \\
\text { parameters }\end{array}$} & \multicolumn{4}{|c|}{ Statistical parameters } \\
\cline { 2 - 5 } & $\mathbf{t}$ & $\mathbf{p}$ & F ratio & $\mathbf{p}$ \\
\hline VO$_{2} \mathbf{m a x}$ & $-4,545$ & 0,000 & 1,566 & 0,506 \\
\hline HRmax & 0,983 & 0,336 & 1,014 & 1,000 \\
\hline Vmax & $-0,473$ & 0,641 & 2,552 & 0,164 \\
\hline V.LT & $-1,436$ & 0,165 & 2,473 & 0,178 \\
\hline V.AT & $-1,203$ & 0,242 & 1,776 & 0,336 \\
\hline HR.LT & $-0,734$ & 0,471 & 1,517 & 0,537 \\
\hline HR.AT & $-0,517$ & 0,610 & 1,959 & 0,315 \\
\hline
\end{tabular}

\section{DISCUSSION}

What is noteworthy in group 1 , are the very low $\mathrm{VO}_{2}$ max values $(49,79 \pm 3,42)$ compared to those recorded by other authors (Bradley et al. 2013, Haugen, Seiler 2015). This occurs also in the case of running effort effectiveness indicators such as: LT, and AT threshold speeds, and maximum speed ( $\mathrm{tab} 2$ ). The $\mathrm{VO}_{2}$ max level is, for this group of competitors, the lowest in the season. The $\mathrm{VO}_{2}$ max level mean does not allow this group of competitors to actively participate in training. Threshold speed values are also too low to actively implement the loads of sufficient volume while keeping the energy balance of the body. (Arnason et al. 2004, Aziz et al. 2007, Mecke et al. 2009, Reilly et al. 2000, Tønnessen et al. 2013, Mecke et al. 2009). Lactate threshold speed (LT) below $11 \mathrm{~km} / \mathrm{h}$, and aerobic threshold speed (AT), below $13 \mathrm{~km} / \mathrm{h}$, do not correspond to the reference values of European leagues' football players (Bradley et al. 2013, Haugen, Seiler 2015). Going back to training after a break which leads to a decrease in aerobic capacity indicators (exceeding $10 \%$ in some contestants), requires an intervention training program, preceding the main one. Thus, the competitors carried out two 6-day micro cycles. Workout volumes in micro cycles I, and 2 differed for different intensity ranges, and were: $\mathrm{I}^{\circ} 28$ and $31 \mathrm{~km}, \mathrm{II}^{\circ} 24$, and $26.5 \mathrm{~km}$, $\mathrm{III}^{\circ} 18$, and $19.8 \mathrm{~km}$. A significant portion of the workouts was done in intensity zones II, and III. In a commonly used stamina shaping methodology, the aerobic capacity reconstructing program is based, during the first micro cycle, on intensities I, and II (McMillan et al. 2005). Considering the short time that could be allotted to the preparations, and the fact that the team had one training program, such a solution was rejected. It is highly probable, that for the group of competitors with a slight decrease in aerobic capacity, such load structure will not be sustaining. Transferring large volumes of workout in the aerobic capacity reconstructing period to aerobic -anaerobic efforts $\left(1 / 2 \mathrm{LT}-\mathrm{AT} \leq \mathrm{II}^{\circ} \leq \mathrm{AT}\right)$, and anaerobic zones $\left(\mathrm{AT} \leq \mathrm{III}^{\circ} \leq \mathrm{AT}+15 \%\right)$, i.e. sub-threshold, and threshold-sub-threshold efforts proved efficient. This solution allows to significantly restore $\mathrm{VO}_{2}$ max levels, and increase the effectiveness of working with V. LT, and V.AT intensities.

\section{CONCLUSIONS}

1. The training program carried out in two 6-day micro cycles, based on load volume total in particular zones: $\mathrm{I}^{\circ} 28$, and $31 \mathrm{~km}, \mathrm{II}^{\circ} 24$, and $26.5 \mathrm{~km}, \mathrm{III}^{\circ} 18$, and $19.8 \mathrm{~km}$ (in microcycles 1 , and 2 , respectively) influences a significant increase in restoring aerobic capacity in competitors after a 14 day detraining period. 
2. The applied 12-day training program resulted in statistically significant changes in basic aerobic capacity indicator values of football players. The increases were: $\mathrm{VO}_{2} \max$ by $12 \%$, V.LT by $7 \%$, and V.AT by $10 \%$. An increase in systole frequency was also achieved at HR.LT, and HR.AT metabolic thresholds.

3. The changes in internal ( $\mathrm{VO}_{2}$ max, HR.LT, and HR. AT), and external (Vmax, V.LT, and V.AT) load indicators of high statistical significance ( $p \leq 0.001-0.005)$, gained over a short time period, make a correction of training intensity zones necessary. Test results have shown, that if there are changes in capacity resulting from the effect of detraining, the diagnostics of the competitor has to be carried out over short time slices. Both positive, and negative changes in the development of his capacity can proceed very fast

4. By choosing the proportions between training loads in intensity ranges I, II, and III, it is possible to include competitors with various levels of aerobic capacity into one training group. The basis of such a solution, is to determine individual workout intensities, while the volume is the same for the whole team.

\section{References}

Arnason A, Sigurdsson S., Gudmundsson A, Holme I, Engebretsen L, Bahr R. (2004). Physical fitness, injuries, and team performance in soccer. Med Sci Sports Exerc., 36, 278-285.

Aziz A., Mukherjee S., Chia M., Teh K. (2007) Relationship between measured maximal oxygen uptake and aerobic endurance performance with running repeated sprint ability in young elite soccer players. J Sports Med Phys Fitness, 47, 401-407.

Bangsbo J., Mizuno M. (1987). Morphological and metabolic alterations in soccer players with detraining and retraining and their relation to performance. In: Reilly B, Lees A, Davids K, et al., editors. Science and football. Proceedings of the First World Congress of Science and Football, 987 Apr 12-17, Liverpool, 114-124.

Bradley P., Carling C., Gomez D., Hood P., Barnes C., Ade J., Boddy M., Krustrup P., Mohr M. (2013). Match performance and physical capacity of players in the top three competitive standards of English professional soccer. Human Movement Science, 32, 808-821.

Costill D., King D., Thomas R. (1986). Effects of reduced training on muscular power in swimmers. Physician Sports Med., $13(2), 94-101$.

Coyle E., Hemmert M., Coggan A. (1986). Effects of detraining on cardiovascular responses to exercise: role of blood volume. J Appl Physiol., 60 (1), 95-99.

Coyle E., Martin III W., Bloomfield S. (1985). Effects of detraining on responses to submaximal exercise. J Appl Physiol., 59 (3), 853-859.

Coyle E., Martin III W., Sinacore D. (1984). Time course of loss of adaptations after stopping prolonged intense endurance training. J Appl Physiol., 57 (6), 1857-1864

Cullinane E., Sady S., Vadeboncoeur L. et al. (1986). Cardiac size and V.O2max do not decrease after short-term exercise cessation. Med Sci Sports Exerc., 18 (4), 420-424.

Ghosh A., Paliwal R., Sam M. (1987). Effect of 4 weeks detraining on aerobic and anaerobic capacity of basketball players and their restoration. Indian J Med Res., 86, 522-527

Haugen T., Seiler S. (2015). Physical and Physiological Testing of Soccer Players: Why, What and How should we Measure? Sportscience, 19, 10-26

Hawley J, Burke L. (1998). Peak performance: training and nutritional strategies for sport. St Leonards: Allen \& Unwin.

Hickson R., Kanakis J., Davis J. (1982). Reduced training duration effects on aerobic power, endurance and cardiac growth. J Appl Physiol., 53 (1), 225-229.

Hickson R., Rosenkoetter M. (1981). Reduced training frequencies and maintenance of increased aerobic power. Med Sci Sports Exerc., 13 (1), 13-16.

Houmard J., Hortobágyi T, Johns R. (1992). Effect of shortterm training cessation on performance measures in distance runners. Int J Sports Med., 13 (8): 572-576

Houmard J., Hortobágyi T., Neufer P. (1993). Training cessation does not alter GLUT-4 protein levels in human skeletal muscle. J Appl Physiol., 74 (2): 776-781

Houston M., Bentzen H., Larsen H. (1979). Interrelationships between skeletal muscle adaptations and performance as studied by detrainingandretraining. Acta Physiol. Scand., 105, 163-70.

Madsen K., Pedersen P., Djurhuus M. (1993). Effectsof detraining on endurance capacity and metabolic changes during prolonged exhaustive exercise. J Appl Physiol., 75 (4), 1444-1451.

Martin III W., Coyle E., Bloomfield S. (1986). Effectsof physical deconditioning after intense endurance training on left ventricular dimensions and stroke volume. J Am Coll Cardiol., 7 (5), 982-989. 
McCoy M., Proietto J., Hargreaves M. (1994). Effect of detraining on GLUT-4 protein in human skeletal muscle. J Appl Physiol., 77 (3), 1532-1536.

McMillan K., Helgerud J., Macdonald R., Hoff J. (2005). Physiological adaptations to soccer specific endurance training in professional youth soccer players. Br J Sports Med., 39, 273-277.

Mikines K., Sonne B., Tronier B. (1989). Effects of acute exercise and detraining on insulin action in trainedmen. J Appl Physiol., 66 (2), 704-711

Moore R., Thacker E., Kelley G. (1987). Effectof training/detraining on submaximal exercise responses in humans. J Appl Physiol., 63 (5), 1719-1724.

Pivarnik J., Senay Jr L. (1986). Effects of exercise detraining and deacclimation to the heat on plasma volume dynamics. Eur J Appl Physiol, 55, 222-228.

Reilly T., Bangsbo J., Franks A. (2000). Anthropometric and physiological predispositions for elite soccer. Journal of Sports Sciences 18, 669-683.

Schneider V, Arnold B, Martin K. (1998). Detraining effects in college football players during the competitive season. J Strength Cond Res., 2 (1), 42-45.

Thoden J. (1991). Testing aerobic power. In: Physiological Testing of the High-Performance Athlete (2nd ed.). J. D. MacDougal, H. A. Wenger, H. J. Green, eds. Champaign, IL :Human Kinetics Books, 107-174.

Thompson P., Cullinane E., Eshleman R. (1984). The effects of caloric restriction or exercise cessation on the serum lipid and lipoprotein concentrations of endurance athletes. Metabolism, 33 (10), 943-950

Tønnessen E., Hem E., Leirstein S., Haugen T., Seiler S. (2013). Maximal aerobic power characteristics of male professional soccer players 1989-2012. International Journal of Sports Physiology and Performance, 8, 323-329.

Vukovich M., Arciero P., Kohrt W. (1996). Changes in insulin action and GLUT-4 with 6 days of inactivity in endurance runners. J Appl Physiol, 80 (1), 240-244

Wasserman, K., Whipp, B., Koyal, S., Beaver, W. (1973). Anaerobic threshold and respiratory gas exchange during exercise. J. Appl. Physiol., 35, 236-243.

Wibom R., Hultman E., Johansson M. (1992). Adaptation of mitochondrial ATPproduction in human skeletal muscle to endurance training and detraining. J Appl Physiol., 73 (5), 2004-10

\section{Corresponding author:}

Tomasz Gabryś: Institute of Physical Education and Sport, State School of Higher Education in Oświęcim, 32-600 Oświęcim, ul. Kolbego 8, Polska Tel: +48 609043828 Email: tomaszek1960@tlen.pl 